\title{
Rice fields as facilitators of freshwater invasions in protected wetlands: the case of Ostracoda (Crustacea) in the Albufera Natural Park (E Spain)
}

\author{
Luis Valls, Juan Rueda and Francesc Mesquita-Joanes
}

\begin{abstract}
Background: Previous studies have identified rice fields in the Mediterranean region as 'hot spots' for the introduction of alien freshwater organisms. Consequently, special attention should be paid when rice fields are located inside or near protected areas for the conservation of native, endangered species. To analyse the relationship between rice field environmental traits and the ecology of aquatic invaders, a study of zoobenthic communities was carried out in JulySeptember 2008 and May-August 2009 in ten rice fields located in the Albufera Natural Park (E Spain), with focus on Ostracoda.

Results: A total of nine ostracod species were found including four considered exotic: Candonocypris novaezelandiae, Stenocypris macedonica, Cypris subglobosa and Hemicypris barbadensis. The presence of H. barbadensis is remarkable, which is recorded for the first time in Europe and S. macedonica in the Iberian Peninsula. A checklist of Ostracoda from Albufera Natural Park is presented, including 11 exotic species, mostly unknown from Holocene sedimentary records. The analysis of ostracod assemblages showed a significant relationship between oxygen content and ostracod species associations, suggesting that their abundance are partially controlled by habitat variables in the rice fields. The exotic species C. novaezelandiae was more abundantly collected in samples with reduced oxygen concentrations, in contrast to other native species whose abundances were lower in such conditions.

Conclusions: Rice fields in Mediterranean areas present a summer inundation period which is unlikely in natural temporary water bodies in the area and which may facilitate invasion by (sub-)tropical species. Lower proportion of exotic to native ostracods is observed in less disturbed areas compared to rice fields with intense human activities. We emphasize the role of anthropogenic effects in the dispersal and colonization processes of exotic ostracods and their particular strong influence in the protected areas closest to rice fields.
\end{abstract}

Keywords: Alien species; Paddy fields; Ostracods; Hemicypris barbadensis; Stenocypris macedonica

\section{Background}

Invasion by alien species is considered second only to habitat loss as a threat to global biodiversity and has its greatest impact in aquatic ecosystems (Mooney and Cleland 2001). Indeed, in recent decades, a general increase in the number of exotic aquatic invertebrates, and ostracods in particular, has been detected in freshwaters (McKenzie and Moroni 1986; Leppäkoski et al. 2002; Rossi et al. 2003).

In the Iberian Peninsula, an increasing number of freshwater ostracods are regarded as exotic species (Baltanás

\footnotetext{
*Correspondence: Luis.Valls@uv.es

Department of Microbiology and Ecology and Cavanilles Institute of Biodiversity and Evolutionary Biology, University of València, Av. Dr. Moliner,
} 50, E-46100 Burjassot, Spain
1992; Baltanás et al. 1996; García-Berthou et al. 2007). Many vectors for the passive dispersal of ostracods have been recognized (Vanschoenwinkel et al. 2008; Sabagh et al. 2011; Aguilar-Alberola et al. 2012), but these do not fully explain their distribution. A vast percentage of these exotic species, mostly with subtropical and tropical origins, are established in the Mediterranean rice fields (Rossi et al. 2003; Escrivà et al. 2012). Among the studied potential vectors, the most important are probably waterbirds and humans (Green and Figuerola 2005; Waterkeyn et al. 2010). In rice fields, evidences point to human activities (e.g. transport of seeds, soil and machinery moving between different areas) as the most important dispersal vector for the introduction of exotic ostracods

\section{实}


from distant regions (Fox 1965; McKenzie and Moroni 1986; Rossi et al. 2003; Escrivà et al. 2012).

Inter- and intra-annual variability of environmental conditions may influence colonisation success by exotic organisms (Davis, 2009). In this framework, ecosystems with physical alteration by human activities, such as rice fields, often present alien species (Ehrenfeld 2011). Shurin (2000) demonstrated that both the probability of successful invasion by colonists and the abundance of alien species once established decline with the increasing diversity of native species. Therefore, human impacts in wetlands through rice field culturing and management activities can produce an increase in probability of alien invertebrates (and ostracods in particular) to be established in the study area.

The Albufera Natural Park (Eastern Iberian Peninsula) is mostly made up of a shallow lake surrounded by rice fields and has a large variety of native ostracods species recorded from interdune and spring ponds (Rueda et al. 2006; Rueda et al. 2013), but an impoverished community in the highly impacted lake itself (Poquet et al. 2008). In this way, this protected area can become a 'hot spot' for invasions because of the facilitation role for the entry and establishment of alien species in disturbed aquatic ecosystems. In addition, these invasion events may increase affected by climate change and globalization (Walther et al. 2009; McGeoch et al. 2010).

In this study, we aimed at evaluating the importance of exotic species in aquatic invertebrate communities, exemplified by ostracods, in modified and strongly human-managed habitats such as rice fields, in comparison with less impacted environments in the same area and in contrast with paleolimnological evidence of past communities. We also planned to test whether or not environmental factors influenced significantly the structure of ostracod communities in such a highly modified environment as rice fields, subjected to strong human impacts and management.

\section{Methods}

Rice fields studied are located in the natural preserve 'Tancat de Zacarés' (UTM: 30S 0729272/4354601), inside the Albufera Natural Park of Valencia (Eastern Iberian Peninsula), at the southern border of the lake, and covering 25.12 ha (Figure 1). Rice fields and Lake Albufera are connected by a web of irrigation canals. We sampled ten different rice fields, each named with codes 'A' to 'J'. No pesticides were used in the restricted area 'Tancat de Zacarés' during the study period.

In the field, $\mathrm{pH}$, oxygen content, conductivity, salinity and water temperature were measured with portable probes. At the same time, we collected water samples for laboratory analyses of alkalinity and chloride, phosphate, nitrate, nitrite and ammonium concentrations. Benthic samples from each rice field were taken in July and September 2008 and again in May, June, July and August 2009 with a D-frame hand net with a mesh size of $100 \mu \mathrm{m}$ over an approximate area of $600 \mathrm{~cm}^{2}$. Sediment obtained

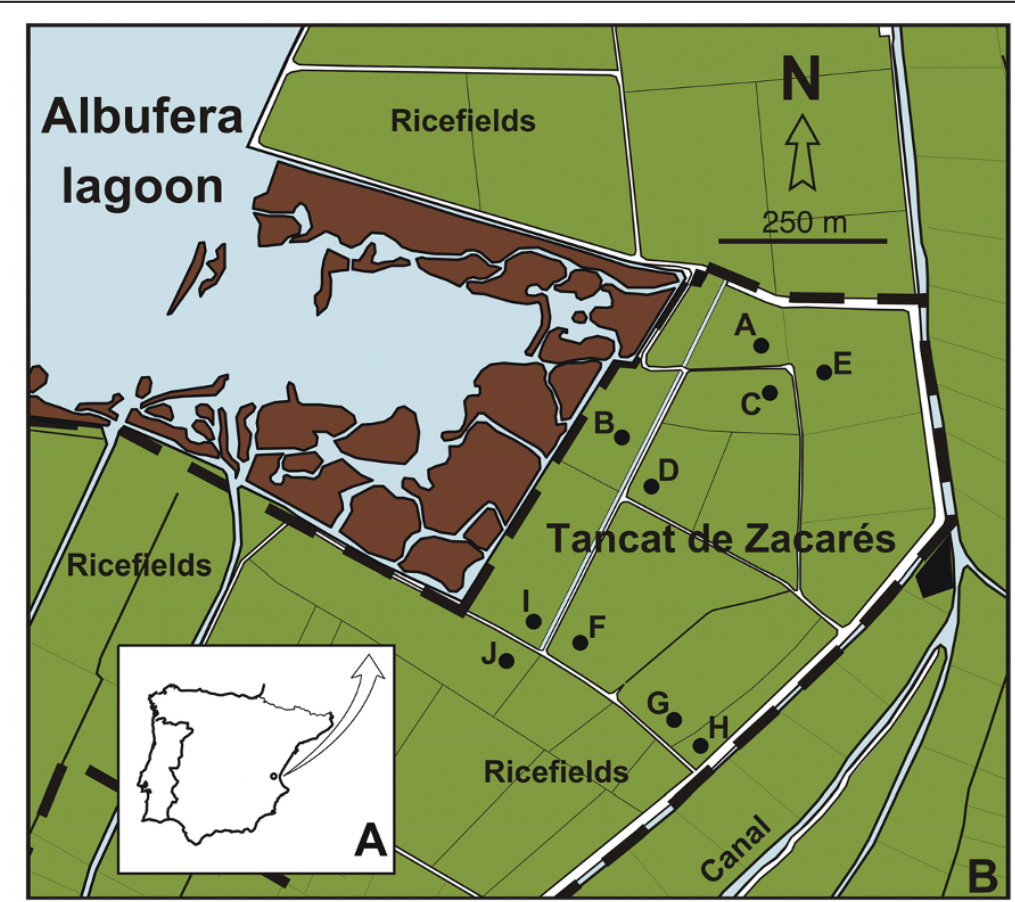

Figure 1 Location of sampling sites. (A, B): (A) general location of sampling area on the Eastern Iberian Peninsula, (B) detailed location of the studied rice fields $A-J$ in the 'Tancat de Zacarés' area in the Albufera Natural Park of Valencia. 
was fixed in the field with $30 \%$ ethanol. In the laboratory, the samples were washed and sieved through a $250-\mu \mathrm{m}$ mesh sieve and stored in $70 \%$ ethanol. When present, ostracods were hand-picked under a stereomicroscope and stored in $70 \%$ ethanol for specific determinations. All complete animals collected alive (i.e. belonging to the biocoenosis) were picked, so as all disarticulated valves and empty shells belonging to the taphocoenosis. Ostracod dissections were prepared following Namiotko et al. (2011), and specimens were determined using the taxonomic publications by Meisch (2000), Broodbakker (1983), Petkovski and Meisch (1996) and Karanovic (2012). We obtained SEM photos of ostracod valves with a Hitachi S-4800 microscope (Hitachi, Ltd, Chiyoda-ku, Japan) at the University of Valencia. We could not take pictures of Dolerocypris sinensis Sars 1903 and Cypris subglobosa Sowerby 1840 because of the poor preservation of their valves.

Species richness and total abundance were calculated for each sample. In addition, community differentiation was quantified with an analysis of similarities (ANOSIM) test, to compare the abundances of species between samples collected either in spring (May-June) or summer (JulySeptember). A similarity percentage (SIMPER) analysis was used for identification and quantification of the species contributing most to the observed differences between these groups of samples.

Species-environment relationships were studied using multivariate constrained ordination. Detrended correspondence analysis (DCA) showed a wide environmental gradient $(\mathrm{SD}>4)$, indicating that some species respond unimodally to underlying ecological gradients (ter Braak and Verdonschot 1995). Consequently, canonical correspondence analysis (CCA) was performed to relate ostracod abundance to their environmental setting and the significance of habitat variables tested with Monte Carlo permutations. The DCA and CCA were performed with CANOCO 5.0 (ter Braak and Šmilauer 2012). ANOSIM,
SIMPER and Spearman correlation analyses were carried out with the software PAST 2.17 (Hammer et al. 2001).

\section{Results}

The rice fields were flooded from April to August, and rice was sown in May. At the end of June 2008 and 2009, water was drained for 14 days. The rice was harvested in September 2008 and August 2009. In the remaining months of the rice cycle, water was drained, and the field substrate was remixed by tractors.

The rice fields included in this study were located close to each other (Figure 1) but varied notably in their environmental conditions. A summary of the physical and chemical features measured in the ten rice fields studied is shown in Table 1. Electrical conductivity at point $\mathrm{G}$ was, on average, higher than $3,300 \mu \mathrm{S} \cdot \mathrm{cm}^{-1}$ while sites $C, E$ and $\mathrm{H}$ showed values below $2,000 \mu \mathrm{S} \cdot \mathrm{cm}^{-1}$. A similar trend was observed for chloride concentration (Spearman rank correlation between conductivity and chloride concentration: $r=0.988 ; p<0.01)$. High phosphate concentrations ( $>15 \mathrm{mg} \cdot \mathrm{L}^{-1}$ ) were found in fields $\mathrm{F}$ and $\mathrm{G}$, while concentrations at $\mathrm{B}, \mathrm{C}, \mathrm{E}$ and $\mathrm{J}$ were below the detection level $\left(<0.05 \mathrm{mg} \cdot \mathrm{L}^{-1}\right)$. Total nitrite concentration was highest in field C (1.83 $\mathrm{mg} \cdot \mathrm{L}^{-1}$ on average), and values were lower than $1.0 \mathrm{mg} \cdot \mathrm{L}^{-1}$ in the other points. The highest ammonia concentrations $\left(>0.9 \mathrm{mg} \cdot \mathrm{L}^{-1}\right)$ were detected in fields $\mathrm{F}, \mathrm{A}$ and I.

Nine ostracod species were recorded among the zoobenthos assemblages in the rice fields during our sampling period (Table 2). Out of these, seven were found alive in the biocoenoses (Figure 2). The most frequent species was Heterocypris salina (Brady 1868), followed by Candonocypris novaezelandiae (Baird 1843) (fields A, D, E, F and J) and Trajancypris clavata (Baird 1838) (fields A, D, E and F). Other species were found in lower abundance values, including Ilyocypris gibba (Ramdohr 1808) (fields B and D), Hemicypris barbadensis Broodbakker 1983 (fields B and J)

Table 1 Mean and standard deviation values of physical and chemical variables analysed during the study period in Zacarés rice fields

\begin{tabular}{|c|c|c|c|c|c|c|c|c|c|c|c|c|c|}
\hline Field & $\mathrm{N}$ & $\mathrm{n}$ & $\begin{array}{c}\text { Cond } \\
\left(\mu \mathrm{S} \cdot \mathrm{cm}^{-1}\right)\end{array}$ & $\begin{array}{c}\mathrm{Sal} \\
\left(\mathrm{g} \cdot \mathrm{L}^{-1}\right)\end{array}$ & $\begin{array}{l}\mathrm{O}_{2} \\
(\%)\end{array}$ & $\begin{array}{l}\text { WT } \\
\left({ }^{\circ} \mathrm{C}\right)\end{array}$ & $\mathrm{pH}$ & $\begin{array}{c}\mathrm{Cl}^{-} \\
\left(\mathrm{mg} \cdot \mathrm{L}^{-1}\right)\end{array}$ & Alk/Cl' & $\begin{array}{c}\mathrm{PO}_{4}^{3-} \\
\left(\mathrm{mg} \cdot \mathrm{L}^{-1}\right)\end{array}$ & $\underset{\left(\mathrm{mg} \cdot \mathrm{L}^{-1}\right)}{\mathrm{NO}_{-}^{-}}$ & $\begin{array}{c}\mathrm{NO}_{2}^{-} \\
\left(\mathrm{mg} \cdot \mathrm{L}^{-1}\right)\end{array}$ & $\underset{\left(m g \cdot L^{-1}\right)}{\mathrm{NH}^{+}}$ \\
\hline$A$ & 5 & 3 & $76 \pm$ & \pm 0.0 & $93.5 \pm 29.4$ & $5.8 \pm 0.6$ & $8.2 \pm 0.7$ & $296 \pm 33$ & $0.65 \pm 0.20$ & $0.06 \pm 0.00$ & $31.5 \pm 2.8$ & $0.12 \pm 0.47$ & $1.70 \pm 0.18$ \\
\hline B & 6 & 4 & $2,906 \pm 402$ & $1.5 \pm 0.2$ & $138.2 \pm 23.2$ & $29.8 \pm 2.6$ & $8.8 \pm 0.5$ & $436 \pm 70$ & $0.38 \pm 0.15$ & $0.00 \pm 0.00$ & $33.7 \pm 11.0$ & $0.05 \pm 0.04$ & $0.58 \pm 0.10$ \\
\hline C & 4 & 4 & $1,980 \pm 184$ & $1.0 \pm 0.1$ & $94.3 \pm 42.1$ & $27.8 \pm 3.5$ & $8.3 \pm 0.1$ & $209 \pm 31$ & $0.82 \pm 0.26$ & $0.00 \pm 0.00$ & $38.3 \pm 12.5$ & $0.71 \pm 1.12$ & $0.35 \pm 0.13$ \\
\hline D & 4 & 4 & $2,503 \pm 749$ & $1.3 \pm 0.4$ & $112.5 \pm 13.6$ & $30.6 \pm 2.3$ & $8.7 \pm 0.5$ & $316 \pm 70$ & $0.64 \pm 0.44$ & $0.10 \pm 0.20$ & $33.7 \pm 11.0$ & $0.03 \pm 0.00$ & $0.35 \pm 0.19$ \\
\hline E & 3 & 3 & $31 \pm 218$ & $0.8 \pm 0.1$ & 50.9 & $29.8 \pm 3.7$ & $8.6 \pm 0.2$ & $152 \pm 60$ & $0.99 \pm 0.02$ & $0.00 \pm 0.00$ & $28.3 \pm 14.1$ & $0.33 \pm 0.27$ & $0.27 \pm 1$ \\
\hline $\mathrm{F}$ & 4 & 3 & $2,610 \pm 337$ & $1.3 \pm 0.2$ & $128.6 \pm 57.2$ & $29.0 \pm 1.4$ & $8.5 \pm 0.4$ & $331 \pm 61$ & $0.48 \pm 0.17$ & $0.17 \pm 0.14$ & $25.0 \pm 8.6$ & $0.11 \pm 0.12$ & $0.97 \pm 0.90$ \\
\hline G & 3 & 2 & $3,393 \pm 1,034$ & 1.8 & 89. & 0 & 8. & 0 & 40 & 0.00 & 1.5 & $0.19 \pm 0.03$ & 0.7 \\
\hline $\mathrm{H}$ & 2 & 1 & $1,845 \pm 50$ & $0.9 \pm 0.0$ & $161.0 \pm 24.7$ & $29.1 \pm 0.1$ & $8.5 \pm 0.1$ & $177 \pm 3$ & $0.73 \pm 0.21$ & $0.07 \pm 0.07$ & $30.0 \pm 0.0$ & $0.78 \pm 0.18$ & $0.05 \pm 0.00$ \\
\hline$T$ & 6 & 2 & $2,376 \pm 410$ & $1.2 \pm 0.2$ & $93.5 \pm 23.5$ & $25.8 \pm 0.6$ & $8.2 \pm 0.3$ & $296 \pm 58$ & $0.65 \pm 0.19$ & $0.06 \pm 0.14$ & $31.5 \pm 12.8$ & $0.12 \pm 0.04$ & $1.70 \pm 0.29$ \\
\hline J & 4 & 3 & $2,506 \pm 548$ & $1.2 \pm 0.3$ & $83.7 \pm 30.6$ & $25.4 \pm 1.0$ & $8.3 \pm 0.2$ & $344 \pm 141$ & $0.53 \pm 0.43$ & $0.00 \pm 0.00$ & $33.0 \pm 4.6$ & $0.03 \pm 0.04$ & $0.53 \pm 0.4$ \\
\hline
\end{tabular}

$N$, number of samples; $n$, number of samples with alive ostracods; $\mathrm{O}_{2}$, oxygen saturation percentage; WT, water temperature. 
Table 2 List of ostracod species found in the Albufera Natural Park

\begin{tabular}{|c|c|c|c|c|c|c|c|}
\hline Species & $\begin{array}{l}\text { Lake } \\
\text { Holocene }\end{array}$ & $\begin{array}{l}\text { Lake (sub-) } \\
\text { recent }\end{array}$ & $\begin{array}{l}\text { Spring } \\
\text { ponds }\end{array}$ & $\begin{array}{l}\text { Rice } \\
\text { fields }\end{array}$ & $\begin{array}{l}\text { S. Llorenç } \\
\text { pond }\end{array}$ & $\begin{array}{l}\text { Interdune } \\
\text { ponds }\end{array}$ & References \\
\hline \multicolumn{8}{|l|}{ Cyprididae Baird 1845} \\
\hline Bradleystrandesia reticulata (Zaddach 1844) & $(1)$ & $0(1)$ & & & & & 5,7 \\
\hline Cypris sp. & $(1)$ & & $0(1)$ & & & & 5,7 \\
\hline C. bispinosa Lucas 1849 & & & $0(1)$ & & & & 7 \\
\hline C. subglobosa Sowerby 1840 & & $0(1)$ & $0(1)$ & $0(1)$ & & & 7,11 \\
\hline Cypridopsis vidua (Müller 1776) & (3) & $0(1)$ & $3(1)$ & & & $10(2)$ & $3,4,5,7,8,9,10$ \\
\hline Plesiocypridopsis newtoni (Brady and Robertson 1870) & & & & & & $0(1)$ & 8 \\
\hline Potamocypris sp. & $(1)$ & & & & & & 3 \\
\hline Sarscypridopsis sp. & & & & & & $0(1)$ & 8 \\
\hline S. aculeata (Costa 1847) & $(1)$ & $0(1)$ & $0(1)$ & & & $16(6)$ & $5,7,8,10$ \\
\hline S. lanzarotensis (Mallwitz 1984) & & & 1 & & & & 9 \\
\hline Hemicypris sp. & $(1)$ & & & & & & 4 \\
\hline H. barbadensis Broodbakker 1983 & & & & $2(1)$ & & & 11 \\
\hline Heterocypris sp. & $(1)$ & & $0(1)$ & & & $5(2)$ & $5,7,8$ \\
\hline H. incongruens (Ramdohr 1808) & & $0(1)$ & 1 & & & $2(1)$ & $7,8,9$ \\
\hline H. cf. rotundata (Bronshtein 1928) & & & $0(1)$ & & & & 7 \\
\hline H. salina (Brady 1868) & $(1)$ & $0(1)$ & $1(1)$ & $9(10)$ & 2 & $25(12)$ & $4,6,7,8,9,10,11$ \\
\hline Dolerocypris sinensis Sars 1903 & & & & $0(1)$ & & & 11 \\
\hline Eucypris pigra (Fisher 1851) & & & & & & $0(1)$ & 8 \\
\hline E. virens (Jurine 1820) & & $0(1)$ & & & & $31(5)$ & $7,8,10$ \\
\hline Trajancypris clavata (Baird 1838) & & & & $6(4)$ & & & 11 \\
\hline Candonocypris novaezelandiae (Baird 1843) & & & & $5(2)$ & & $3(2)$ & 10,11 \\
\hline Herpetocypris sp. & $(1)$ & & & & & & 3 \\
\hline H. cf. chevreuxi (Sars 1896) & $(2)$ & $0(1)$ & & & & & 5,7 \\
\hline Stenocypris macedonica Petkovski and Meisch 1996 & & & & 1 & & & 11 \\
\hline S. major (Brady 1868) & & & $1(1)$ & & & & 7,9 \\
\hline Isocypris beauchampi (Paris 1920) & & $0(1)$ & 2 & & & & 7,9 \\
\hline \multicolumn{8}{|l|}{ Candonidae Kaufmann 1990} \\
\hline Candona sp. & $(1)$ & & & & & & 3 \\
\hline C. angulata G. W. Müller 1900 & (3) & $0(1)$ & $0(1)$ & & & & $3,4,5,7$ \\
\hline C. neglecta Sars 1887 & & & $0(1)$ & & & & 7 \\
\hline Fabaeformiscandona cf. brevicornis (Klie 1940) & & & $0(1)$ & & & & 7 \\
\hline F. cf. latens (Klie 1940) & & $0(1)$ & & & & $0(1)$ & 7,8 \\
\hline F. subacuta (Yang 1982) & & $0(1)$ & $1(1)$ & 2 & & $2(1)$ & $2,7,8,9,10,11$ \\
\hline Pseudocandona cf. albicans (Brady 1864) & & & 1 & & (1) & & 6,9 \\
\hline P. cf. marchica (Hartwig 1889) & & $0(1)$ & $1(1)$ & & & & 7,9 \\
\hline P. pratensis (Hartwig 1901) & & & & & & $6(4)$ & 8 \\
\hline Candonopsis kingsleii (Brady and Robertson 1870) & & & $2(1)$ & & & & 7,9 \\
\hline C. scourfieldi Brady 1910 & & & $1(1)$ & & & & 7 \\
\hline Cypria sp. & $(1)$ & & & & & & 5 \\
\hline C. ophtalmica (Jurine 1820) & $(1)$ & $0(1)$ & $3(1)$ & & & & $3,7,9$ \\
\hline C. cf. subsalsa Redeke 1936 & & & $0(1)$ & & & & 7 \\
\hline
\end{tabular}


Table 2 List of ostracod species found in the Albufera Natural Park (Continued)

\author{
llyocyprididae Kaufmann 1900 \\ Ilyocypris gibba (Ramdohr 1808) \\ I. monstrifica (Norman 1862)
}

Darwinulidae Brady and Robertson 1885

Darwinula stevensoni (Brady and Robertson 1870)

Vestalenula sp.

Cushmanideidae Puri 1973

Pontocythere cf. rubra Müller 1894

P. cf. turbida Müller 1894

Cytherideidae Kollmann 1960

Cyprideis torosa (Jones 1850)

Entocytheridae Hoff 1942

Ankylocythere sinuosa (Rioja 1942)

Hemicytheridae Puri 1953

Aurila arborescens (Brady 1865)

Leptocytheridae Sars 1925

Leptocythere sp.

L. cf. porcellanea (Brady, 1869)

Limnocytheridae Klie 1938

Limnocythere inopinata (Baird 1843)

L. stationis Vavra 1891

Paralimnocythere psammophila (Flössner 1965)

Loxoconchidae Sars 1925

Loxoconcha elliptica Brady 1868

L. rhomboidea (Fischer 1855)

Paradoxostomatidae Brady and Norman 1889

Cytherois sp.

$$
0(1)
$$

$3(1)$

$4(1)$

2 (4)

$0(1)$

(3)

0 (1)

0 (1)

$3(1)$

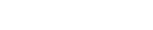

(2)

(2)

(3)

(2)

C. cf. stephanidesi Kile 1983

(1)

Xestoleberidae Sars 1866

Xestoleberis nitida (Liljeborg 1853)

(3)

$0 / 29$

$0(1)$

$0(1)$

$0(1)$

$0(1)$

2

1

$0(1)$

Total number of exotics/natives

0 (1)

$2(2)$

$3,5,7,8,9$

$3,5,6$

$3,5,7$

$3,4,5,7$

0 (1) $\quad 3,4,8$

Numbers of samples where alive specimens (without parentheses) or only shell remains (in parentheses) were found are indicated for each type of environment or period (sedimentary Holocene records as 'Holocene'; (sub-)recent samples for the rest). Numbers of samples for species considered (putatively) exotic are shown in italics. Numbers of exotic and native species are shown in bold. References: 1: Aguilar-Alberola et al. 2012; 2: Escrivà et al. 2012; 3: Marco-Barba 2010; 4: Marco-Barba et al. 2013a; 5: Marco-Barba et al. 2013b; 6: Mezquita et al. 2005; 7: Poquet et al. 2008; 8: Rueda et al. 2006; 9: Rueda et al. 2013; 10: Valls et al. 2013; 11: This study.

and Stenocypris macedonica Petkovski and Meisch 1996 collected only in field B. All of these species were also found in the taphocoenoses. One juvenile of Fabaeformiscandona sp. was collected but could not be further identified to species level. Furthermore, D. sinensis and $C$. subglobosa were only represented in the taphocoenoses (fields B and J, respectively).

The majority of the species found in this study can be considered non-indigenous species in Europe (see, e.g. Griffiths 1995; Meisch 2000). One of the most singular exotic species collected is $H$. barbadensis (Figure 2A, B, C, $\mathrm{D}, \mathrm{E}, \mathrm{F})$, as this is the first citation of the species for Europe.
Moreover, this is the first time that $S$. macedonica (Figure 2I) is detected in the Iberian Peninsula. The other exotic species collected alive in the Zacarés rice fields are also rare in Europe. This is the case of the exotic ostracod C. novaezelandiae (Figure $2 \mathrm{G}, \mathrm{H}$ ) that has been only recorded in nearby areas (Valls et al. 2013). Pustules located in the posteroventral inner list of the left valve of $C$. novaezelandiae (Figure $2 \mathrm{H}$ ), a trait previously recognized in individuals from a nearby population in Racó de l'Olla (Valls et al. 2013), were observed again and seem to account for a morphological trait of the species that was previously unnoticed. 


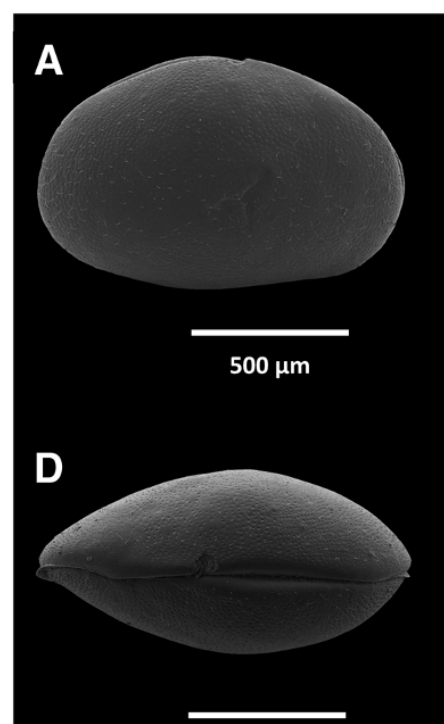

$500 \mu \mathrm{m}$
B

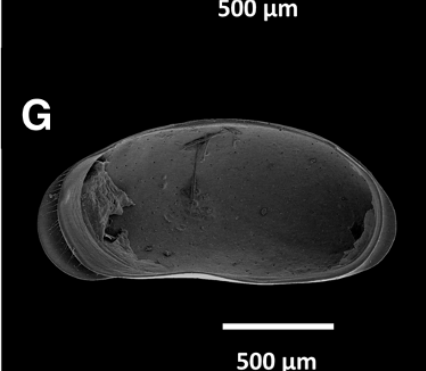

$500 \mu \mathrm{m}$

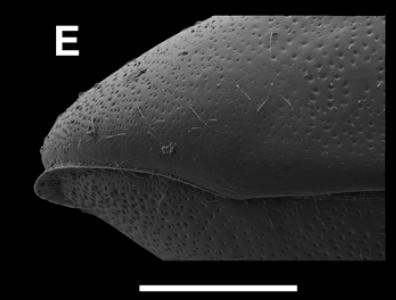

$200 \mu \mathrm{m}$

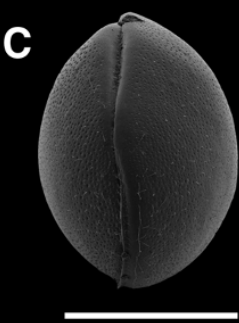

$500 \mu \mathrm{m}$

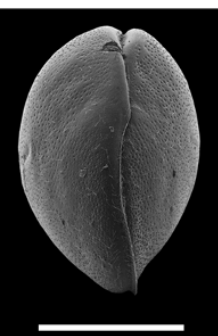

$500 \mu \mathrm{m}$

$\mathbf{F}$

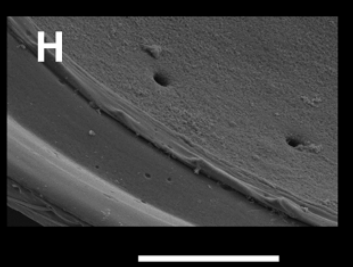

$50 \mu \mathrm{m}$
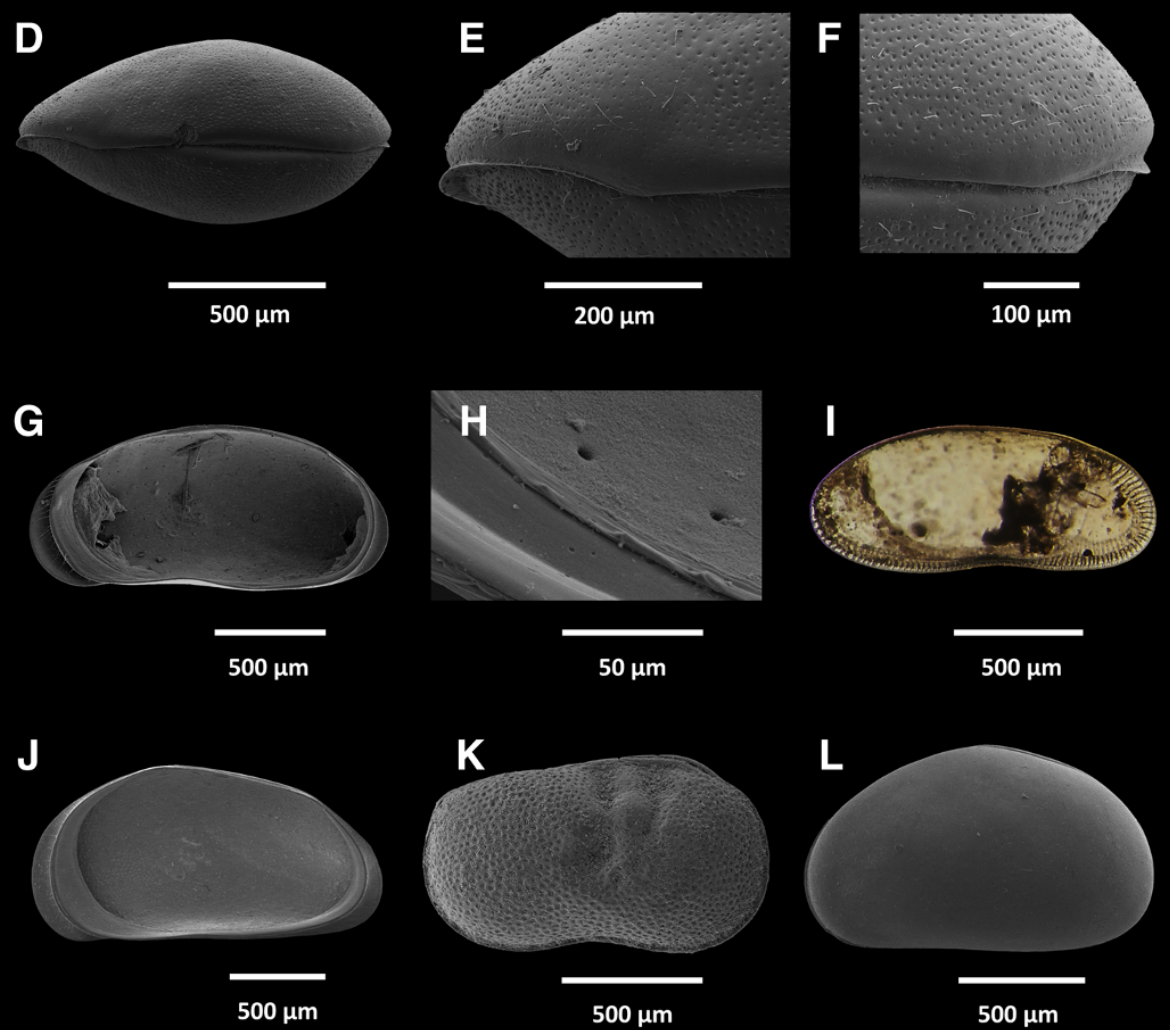

K

I

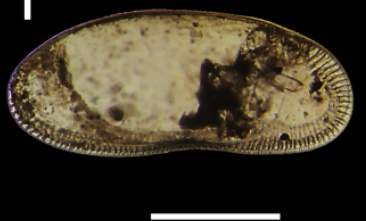

$500 \mu \mathrm{m}$

Figure 2 SEM and stereomicroscope pictures of ostracod species found in Zacarés. (A-F): Hemicypris barbadensis Broodbakker 1983. (A) External view of the right valve (RV), (B) carapace in anterior view, (C) carapace in posterior view, (D) carapace in dorsal view, (E) detail of the antero-dorsal view and (F) detail of the postero-dorsal view. (G-H) Candonocypris novaezelandiae (Baird, 1843). (G) Inner view of the RV and (H) detail inner list of the left valve (LV). (I) Stenocypris macedonica Petkovski and Meisch 1996, external view of the RV. (J) Trajancypris clavata (Baird 1838), inner view of the RV. (K) Ilyocypris gibba (Ramdohr, 1808), external view of the RV. (L) Heterocypris salina (Brady, 1868), external view of the LV.

In order to compare the studied rice fields with other nearby habitats, we built a checklist of ostracods from the Albufera Natural Park, shown in Table 2. In all, 59 ostracod species have been recorded in the area; 27 of them were found alive and 32 were represented only in taphocoenoses. Some species present in Zacarés rice fields were never found in paleolimnologic studies carried out in Lake Albufera (Santisteban et al. 2009; Marco-Barba et al. 2013a, b). This confirms that $H$. barbadensis, C. novaezelandiae, S. macedonica, C. subglobosa and D. sinensis could be considered exotic species in this protected area. However, it should be noticed that Hemicypris sp. found in earlier
Holocene records could have probably colonized the area through bird dispersion from Africa, where this genus is widely distributed (Martens 1984). A similar process could be related to Sarscypridopsis lanzarotensis (Mallwitz 1984), common in the Canary Islands (Malmqvist et al. 1997), and perhaps in northern Africa as well. The species identified as Stenocypris major (Brady 1868) by Poquet et al. (2008) should be taken with caution, as these authors did not take into account the review of the genus by Petkovski and Meisch (1996).

Figure 3 shows the mean abundance of three species common to the studied Zacarés rice fields, two species 


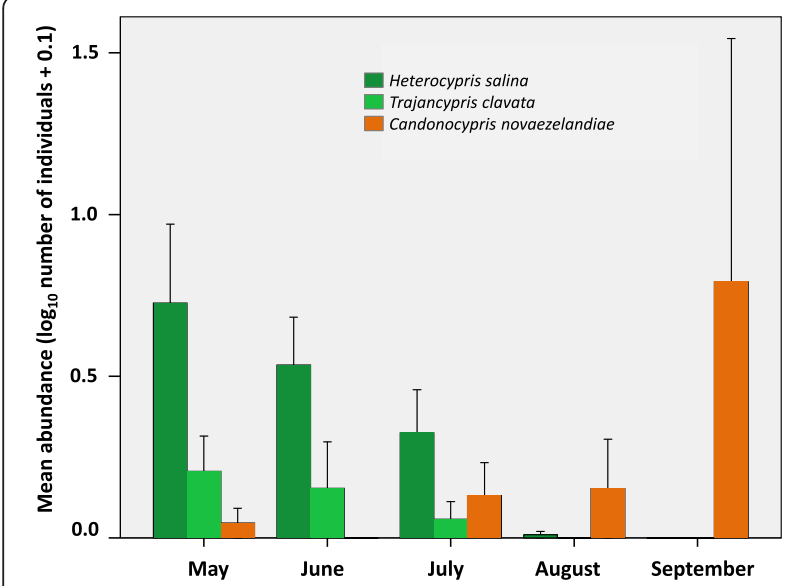

Figure 3 Temporal dynamics of ostracod species abundance. Mean abundance ( $\log _{10}$ number of individuals +0.1 ) and standard deviation values for the most common ostracods in Zacarés rice fields in different sampling months. Heterocypris salina: dark green; Trajancypris clavata: light green; and Candonocypris novaezelandiae: orange.

common in Mediterranean temporary habitats (H. salina and $T$. clavata) and one alien species (C. novaezelandiae). High abundance of native species and the lowest of the alien species were found in May and June. On the other hand, in July and August, abundances of native species decreased and C. novaezelandiae abundances increased. The results of ANOSIM indicated significant differences $(p=0.013)$ in community structure between sampling periods. According to posterior SIMPER analysis, samples collected in May-June were dominated by $H$. salina and $T$. clavata, while those collected later in summer (JulySeptember) were dominated by $C$. novaezelandiae. These three species together accumulated $c .84 \%$ of the differences between these sampling periods.

CCA was carried out after applying DCA, which indicated a gradient length of 4.49 SD. In CCA, Monte Carlo permutation tests in a forward selection analysis indicated that only oxygen content was significant $(p=0.007)$ in explaining ostracod community composition with the set of variables used, whereas alkalinity and $\mathrm{NH}_{4}^{+}$were the next variables in order of contribution but were not significant ( $p=0.09$ and $p=0.12$, respectively) (Figure 4 ). Axis 1 accounted for $14.83 \%$ of the explained variance and axis 2 for $5.11 \%$. Exotic species C. novaezelandiae and $H$. barbadensis were ordered in relation to low oxygen concentrations. A temporal gradient in the oxygen content was noticed: higher levels corresponded to May and June months and, by the end of summer (July-September), rice fields presented low oxygen concentration and high relative bicarbonate and ammonia concentrations.

\section{Discussion}

Williamson (1996) proposed three main stages in biological invasion processes, i.e. arrival, establishment and spread. As Blackburn et al. (2011) pointed out, each stage can be delimited by a particular type of barrier. Understanding these barriers and factors that influence invasion success is essential to determine the role of alien species in

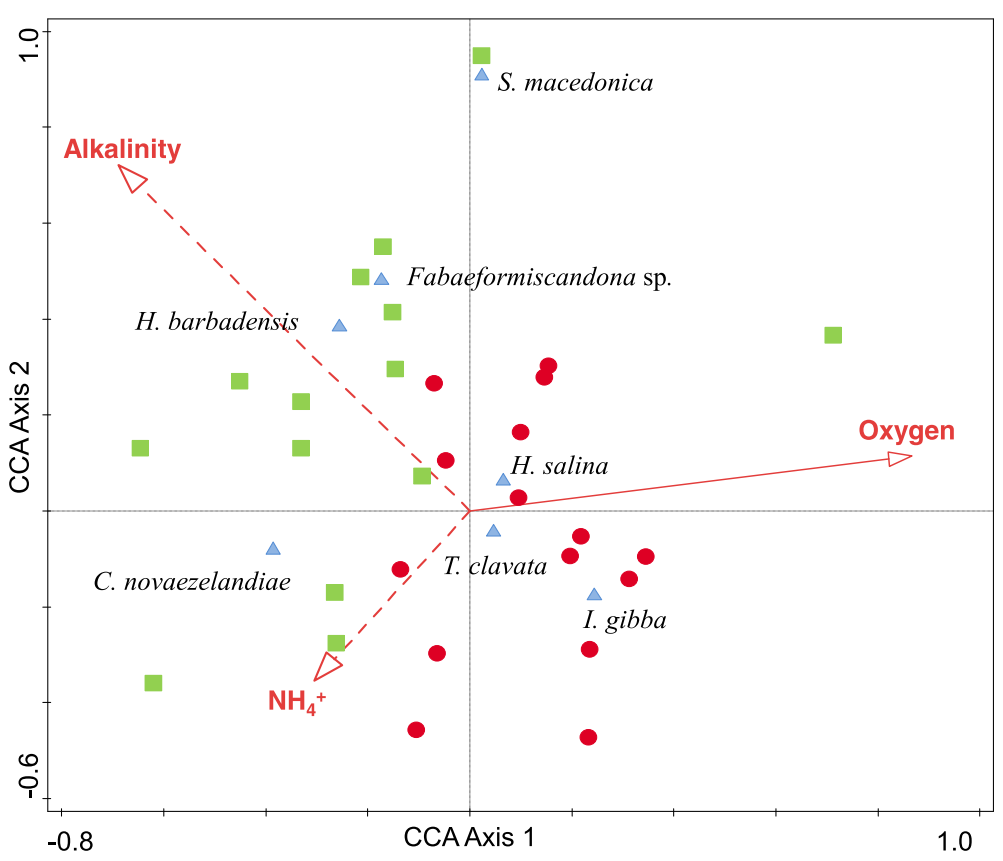

Figure 4 Canonical correspondence analysis (CCA). Triplot graph of CCA showing ordination of species, samples and environmental variables from Zacarés rice fields in the first two axes. Blue triangles: species scores. Red circles: samples taken in May-June. Green squares: samples collected in JulySeptember. Solid line arrow: significant $(p<0.05)$. Dashed line arrows: not significant $(0.2>p>0.05)$. See text for further explanation. 
ecosystems. In this frame, we focused on how physical and chemical aspects and dispersal mechanisms could affect the processes of aquatic invasion by exotic Ostracoda in the study area.

In the colonization stage, physiological problems are considered the most important barrier for the establishment of alien species (Lomolino et al. 2010). In this sense, rice field ecosystems in the Mediterranean may be particularly fitted for alien species of tropical origin compared to native species (Martens and Toguebaye 1985; Forès 1988). These are temporary water bodies filled in hot, summer periods. Such combination of habitat conditions is extremely rare, if present at all, around the Mediterranean, where summers are extremely dry and temporary water bodies are filled usually in the colder months of autumn, winter or spring, but hardly ever in summer. Conversely, many tropical temporary waters experience high temperatures, and species adapted to such conditions, including ostracods such as $C$. novaezelandiae, $S$. macedonica and $H$. barbadensis, may find an empty niche in Mediterranean areas. The world distribution of these and other exotic ostracods shows that they are successful colonizers of rice fields worldwide, but particularly in (sub-)tropical areas. H. barbadensis was reported in the Barbados and Japanese rice fields (Broodbakker 1983; Okubo 1990) and from a permanent lake in Jamaica (Holmes 1997). Candonocypris novaezelandiae has indeed a wider distribution area, as it is present in lakes and ponds in Australia, New Zealand, New Caledonia islands, China, Spain and South Africa (Sars 1924; De Deckker 1981; De Deckker 1983; Martens 1984; Eagar 1994; Martens et al. 1998; Yu et al. 2010; Valls et al. 2013), in the river Nile (Ebtesam 2010) and in fishponds in Japan (Okubo 1975). Also, C. subglobosa has been commonly cited in worldwide tropical wetlands, usually including rice fields, from Africa, America, Asia and Europe (Martens and Toguebaye 1985). These authors remark on the tropicallike functioning of rice field ecosystems in temperate areas.

In spite of this facilitation to exotic ostracod species to colonize the Albufera Natural Park, particularly in rice fields and surroundings (Table 2), most of these are not usually found outside this type of environments. However, some exotic species seem to be pre-adapted to tolerate the conditions of other temperate water bodies. This might be the case for C. novaezelandiae, which is not only found in paddy fields in the newly colonized continent (e.g. Valls et al. 2013) but is also able to jump to other types of (disturbed) water bodies such as reservoirs (Escrivà et al. 2014). A similar case is exemplified by Fabaeformiscandona subacuta (Yang 1982), an exotic ostracod of Asian origin in the Iberian Peninsula, which apparently dispersed from rice fields to the Albufera Natural Park and other inland areas (Escrivà et al. 2012). This species is widely distributed, and its invasion history reflects the potential problem that we discuss in the present survey. In fact, the presence of $F$. subacuta in Iberian reservoirs could be related to low oxygen concentration (Escrivà et al. 2014), similarly as to the relationship found in this survey of rice fields where the exotic $H$. barbadensis and C. novaezelandiae related to the more reduced environments, with low oxygen content in the negative side of the CCA ordination axis (Figure 4). C. novaezelandiae and $H$. barbadensis were found only in summer (July and August) (Figure 3) when oxygen presented low values (Figure 4), but alkalinity and ammonium increased. Hence, these conditions where exotic species were present correspond to highly eutrophicated and disturbed environments, with strong dominance of respiration processes related to organic matter decomposition. However, these findings still need corroboration because oxygen content can be highly variable in rice fields and other aquatic systems (Quesada et al. 1997), and we did not measure daily variability to ascertain that our measures taking during the day correlated with night oxygen content values (expected to be much lower). Anyway, under some circumstances in which water bodies are closer to their pristine state, the high diversity of native ostracods might hinder the invasion by exotic species, i.e. the diversity-invasibility hypothesis (but see Davis 2009). The relatively high ostracod diversity in this natural park (Table 2) could therefore reduce the possibility of further colonization by alien species, which seem to be more successful in the disturbed rice field areas.

Other studies about ostracod diversity in rice fields in Japan (Okubo 1990), Italy (Fox 1965; Rossi et al. 2003) and Spain (Forès 1988) also show high levels of xenodiversity. This suggests that dispersal and colonization abilities of exotic ostracods in dynamic and anthropized environments could be higher than those in more preserved habitat types. F. subacuta was most probably transported to the Iberian Peninsula by human activities. Rice trading might have been the vector accounting for such longdistance ostracod dispersal, as discussed by McKenzie and Moroni (1986) and others (Fox 1965; Forès 1988; Rossi et al. 2003). Devising measures to prevent these dispersal events by human activities is therefore imperative (McGeoch et al. 2010).

\section{Conclusions}

The ostracod assemblages analysed in Zacarés rice fields reveal a significant relationship between species composition and environmental conditions, in particular reduced oxygen content in summer compared to spring samples, suggesting species sorting effects in the structuring processes of these communities in the area. Among the species found, the high proportion of exotic species of (sub-)tropical origin is remarkable, including H. barbadensis, recorded for the first time in Europe, S. macedonica and C. novaezelandiae. A higher ratio of native to exotic 
species is found in rice fields compared to other environments of the Albufera Natural Park, suggesting that these habitats function as facilitators for the establishment of alien species. Rice fields are probably the only temporary environments that follow the opposite trend to most other temporary Mediterranean water bodies, being flooded during the warmest and driest summer months. This humanmanaged artificial hydroperiod allows the colonization of the area by exotic ostracods from other continents, some of which might invade other habitat types, with unknown consequences for the native fauna.

\section{Competing interests}

The authors declare that they have no competing interests.

\section{Authors' contributions}

$J R$ and FM conceived the research and performed the analysis. JR collected the specimens and field data. JR and LV performed the laboratory work. LV wrote the first version of the manuscript with help from JR with the figures. JR and FM made modifications to the manuscript. All authors read and approved the final manuscript.

\section{Acknowledgements}

We would like to thank SEO/BirdLife (Valencia) for the assistance in collecting the samples. The SCSIE Microscopy personnel at the University of Valencia are acknowledged for their help with SEM imaging. We thank J. A. Aguilar-Alberola, A. Escrivà, A. Castillo-Escrivà and two anonymous reviewers for their suggestions and comments. Partial funding has been received from the Spanish Ministry of Science and Innovation and Ministry of Economy and Competitiveness through projects ECOINVADER (CGL2008-01296/BOS) and ECOLAKE (CGL2012-38909).

Received: 14 April 2014 Accepted: 10 September 2014

Published online: 19 September 2014

\section{References}

Aquilar-Alberola JA, Mesquita-Joanes F, López S, Mestre A, Casanova JC, Rueda J, Ribas A (2012) An invaded invader: high prevalence of entocytherid ostracods in the red swamp crayfish Procambarus clarkii (Girard, 1852) in the Eastern Iberian Peninsula. Hydrobiologia 688:63-73

Baltanás A (1992) A contribution to the knowledge of cypridid ostracode fauna (Crustacea, Ostracoda, Cyprididae) on the Iberian peninsula, and a comparison with adjacent areas. Arch Hydrobiol 90:419-452

Baltanás A, Beroiz B, López A (1996) Lista faunística y bibliográfica de los ostrácodos no-marinos (Crustacea, Ostracoda) de la Península Ibérica, Islas Baleares e Islas Canarias. Asociación Española de Limnología, Madrid

Blackburn TM, Pyšek P, Bacher S, Carlton TP, Duncan RP, Jarošík V, Wilson JRU, Richardson DM (2011) A proposed unified framework for biological invasions. Trends Ecol Evol 26:333-339

Broodbakker NW (1983) The genus Hemicypris (Crustacea, Ostracoda) in the West Indies. Bijdr Dierkd 53:135-157

Davis MA (2009) Invasion Biology. Oxford University Press, New York

De Deckker P (1981) Ostracoda from Australian inland waters - notes on taxonomy and ecology. Proc R Soc Vic 93:43-85

De Deckker $P$ (1983) Notes on the ecology and distribution of non-marine ostracods in Australia. Hydrobiologia 106:223-234

Eagar SH (1994) Freshwater Ostracoda from Eastern North Island, New Zealand. N Z Nat Sci 21:71-86

Ebtesam AY (2010) Taxonomy and description of the female Candonocypris novaezelandiae (Baird, 1843) (Crustacea: Ostracoda) from River Nile, Sohag Governorate, Egypt. Egypt Acad J Biol 2:61-69

Ehrenfeld JG (2011) Ecosystem consequences of biological invasions. Annu Rev Ecol Evol Syst 41:59-80

Escrivà A, Smith RJ, Aguilar-Alberola JA, Kamiya T, Karanovic I, Rueda J, Schornikov El, Mesquita-Joanes F (2012) Global distribution of Fabaeformiscandona subacuta: an exotic invasive Ostracoda on the Iberian Peninsula? J Crustac Biol 32:949-961

Escrivà A, Rueda J, Armengol X, Mesquita-Joanes F (2014) Artificial dam lakes as suitable habitats for exotic invertebrates: Ostracoda ecology and distribution in reservoirs of the Eastern Iberian Peninsula. Knowl Managt Aquatic Ecosyst 412:09
Forès E (1988) Els ostràcodes dels arrosals del delta de l'Ebre: Sistemàtica, ecología i distribució geogràfica. Butll Inst Cat Hist Nat 55:47-57

Fox HM (1965) Ostracod Crustacea from ricefields in Italy. Mem Ist ital Idrobiol 18:205-214

García-Berthou E, Boix D, Clavero M (2007) Non-indigenous animal species naturalized in Iberian inland waters. In: Gherardi F (ed) Biological Invaders in Inland Waters: Profiles, Distribution, and Threats. Springer, Spain, pp 123-140

Green AJ, Figuerola F (2005) Recent advances in the study of long distance dispersal of aquatic invertebrates via birds. Divers Distrib 11:149-156

Griffiths HI (1995) European Quaternary freshwater Ostracoda: a biostratigraphic and palaeobiogeographic primer. Scopolia 34:1-168

Hammer O, Harper DAT, Ryan PD (2001) PAST: Palaeontological Statistics software package for education and data analysis. Palaeontol Electron 4:9

Holmes JA (1997) Recent non-marine Ostracoda from Jamaica, West Indies. J Micropalaeontol 16:137-143

Karanovic I (2012) Recent Freshwater Ostracods of the World. Springer, Heidelberg

Leppäkoski E, Gollasch S, Olenin S (2002) Invasive Aquatic Species of Europe: Distribution, Impacts and Management. Kluwer, Dordrecht, the Netherlands

Lomolino MV, Riddle BR, Brown JA (2010) Biogeography, 4th edn. Sinauer Associates, Inc., Massachussetts

Malmqvist B, Meisch C, Nilsson AN (1997) Distribution patterns of freshwater Ostracoda (Crustacea) in the Canary Islands with regards to habitat use and biogeography. Hydrobiologia 347:159-170

Marco-Barba J, Holmes JA, Mesquita-Joanes F, Miracle MR (2013a) The influence of climate and sea-level change on the Holocene evolution of a Mediterranean coastal lagoon: evidence from ostracod palaeoecology and geochemistry. Geobios 46:409-421

Marco-Barba J, Mesquita-Joanes F, Miracle MR (2013b) Ostracod palaeolimnological analysis reveals drastic historical changes in salinity, eutrophication and biodiversity loss in a coastal Mediterranean lake. Holocene 23:556-567

Martens K (1984) Annotated checklist of non-marine ostracods (Crustacea, Ostracoda) from African inland waters. Zool Dokum, K Mus Midden Afrika 20:1-51

Martens K, Toguebaye BS (1985) On the presence of Cypris subglobosa Sowerby, 1840 (Crustacea, Ostracoda) in Africa, with notes on the distribution of this species. Ann Soc Roy Zool Bel 115:147-153

Martens K, Hamer H, Coke M (1998) A preliminary account of the diversity of nonmarine Ostracoda (Crustacea) in Kwazulu-natal, South Africa. Lammergeyer 45:17-31

McGeoch MA, Butchart SHM, Spear D, Marais E, Kleynhans EJ, Symes A, Chanson A, Hoffmann M (2010) Global indicators of biological invasion: species numbers, biodiversity impact and policy responses. Divers Distrib 16:95-108

McKenzie KG, Moroni A (1986) Man as an agent of crustacean passive dispersal via useful plants-exemplified by Ostracoda ospiti esteri of the Italian ricefiels ecosystem —and implications arising therefrom. J Crustac Biol 6:181-198

Meisch C (2000) Crustacea: Ostracoda. In: Schwoerbel J, Zwick P (eds) Süßwasserfauna von Mitteleuropa. Heidelberg, Berlin, Spektrum Akad. Verl

Mezquita F, Roca JR, Reed JM, Wansard G (2005) Quantifying species-environment relationships in non-marine Ostracoda: Examples using Iberian data. Palaeogeogr Palaeoclimatol Palaeoecol 225:93-117

Mooney HA, Cleland E (2001) The evolutionary impact of invasive species. Proc Nat Acad Sci 98:5446-5451

Namiotko T, Danielopol DL, Baltanás A (2011) Soft body morphology, dissection and slide-preparation of Ostracoda: a primer. Joannea-Geol Paläeont 11:327-343

Okubo I (1975) Studies on Ostracoda in fishponds-1. Two species in fishponds of the Chiba Prefectural Freshwater Fisheries Experimental Station. Bull Jpn Soc Sci Fish 41:155-165

Okubo I (1990) Sixteen species of freshwater Ostracoda from Japan (freshwater Ostracoda from Japan, XV). Bull Biogeogr Soc Jpn 45:39-50

Petkovski T, Meisch C (1996) Species of the Genus Stenocypris Sars, 1889 from the rice-fields of Macedonia (Crustacea, Ostracoda). Bull Sci Mus Nat Hist Luxemburg 23:57-85

Poquet JM, Mezquita F, Rueda J, Miracle MR (2008) Loss of Ostracoda biodiversity in Western Mediterranean wetlands. Aquat Conserv Mar Freshw Ecosyst 18:280-296

Quesada A, Leganés F, Fernández-Valiente E (1997) Environmental factors controlling $\mathrm{N}_{2}$ fixation in Mediterranean rice fields. Microb Ecol 34:39-48

Rossi V, Benassi G, Veneri M, Bellavere C, Menozzi P, Moroni A, McKenzie KG (2003) Ostracoda of the Italian ricefields thirty years on: new synthesis and hypothesis. J Limnol 62:1-8

Rueda J, Aguilar-Alberola JA, Mezquita F (2006) Contribución al conocimiento de los crustáceos (Arthropoda, Crustacea) de las Malladas de la Devesa del Parque Natural de la Albufera (Valencia). Bol Asoc Esp Entomol 30:9-29 
Rueda J, Mesquita-Joanes F, Valentín A, Dies B (2013) Inventario de los macroinvertebrados acuáticos del "Ullal de Baldovi" (Sueca, Valencia, España) tras un programa de restauración. Bol R Soc Esp Hist Nat Sec Biol 107:1-9

Sabagh LT, Dias RJP, Branco CWC, Rocha CFC (2011) News records of phoresy and hyperphoresy among treefrogs, ostracods, and ciliates in bromeliad of Atlantic forest. Biodivers Conserv 20:1837-1841

Santisteban CD, Marco-Barba J, Miracle MR (2009) La evolución Holocena de la Albufera de Valencia. Geogaceta 46:99-102

Sars GO (1924) The freshwater Entomostraca of the Cape Province (Union of South Africa) Ostracoda. Ann S Afr Mus 20:105-193

Shurin JB (2000) Dispersal limitation, invasion resistance, and the structure of pond zooplankton communities. Ecology 81:3074-3086

ter Braak CJF, Smilauer P (2012) Canoco Reference Manual and User's Guide: Software for Ordination, Version 5.0. Microcomputer Power, New York, Ithaca USA

ter Braak CJF, Verdonschot PF (1995) Canonical correspondence analysis and related multivariate methods in aquatic ecology. Aquat Sci 57:255-289

Valls L, Rueda J, Mesquita-Joanes F (2013) Dynamics of Ostracoda (Crustacea) assemblages in a Mediterranean pond system (Racó de l'Olla, Albufera Nat. Park) with focus on the exotic species Candonocypris novaezelandiae (Baird, 1843). Ann Limnol-Int J Lim 49:237-247

Vanschoenwinkel B, Waterkeyn A, Vandecaetsbeeck T, Pineau O, Grillas P, Brendonck L (2008) Dispersal of freshwater invertebrates by large terrestrial mammals: a case study with wild boar (Sus scrofa) in Mediterranean wetlands. Freshw Biol 53:2264-2273

Walther GR, Roques A, Hulmes PE, Sykes MT, Pyšek P, Kühn I, Zobel M, Bacher S, Botta-Dukát Z, Bugmann H, Czúcz B, Dauber J, Hickler T, Jarošík V, Kenis M, Klotz S, Minchin D, Moora M, Nentwig W, Ott J, Panov VE, Reineking B, Robinet C, Semenchenko V, Solarz W, Thuiller W, Vilà M, Vohland K, Settele J (2009) Alien species in a warmer world: risks and opportunities. Trends Ecol Evol 24:686-693 Waterkeyn A, Vanschoenwinkel B, Elsen S, Anton-Pardo M, Grillas P, Brendonck L (2010) Unintentional dispersal of aquatic invertebrates via footwear and motor vehicles in a Mediterranean wetland area. Aquat Conserv 20:580-587

Williamson M (1996) Biological Invasions. Chapman and Hall, London, England Yu N, Zhao Q, Cheng X (2010) New records of freshwater Ostracoda from the Dianchi lake, Yunnan province, SW China. Acta Micropaleontol Sin 27:344-350

doi:10.1186/s40555-014-0068-5

Cite this article as: Valls et al:: Rice fields as facilitators of freshwater invasions in protected wetlands: the case of Ostracoda (Crustacea) in the Albufera Natural Park (E Spain). Zoological Studies 2014 53:68.

\section{Submit your manuscript to a SpringerOpen ${ }^{\odot}$ journal and benefit from:}

- Convenient online submission

- Rigorous peer review

- Immediate publication on acceptance

- Open access: articles freely available online

- High visibility within the field

- Retaining the copyright to your article

Submit your next manuscript at $>$ springeropen.com 